\title{
Vertical distribution of different forms of potassium and their relationship with different soil properties in some Haryana soil under different crop rotation
}

\begin{abstract}
Distribution of different forms of potassium in soils from different crop rotations (pearl millet-wheat; cotton-wheat; pearl millet-mustard; paddy-wheat; sorghum-wheat) in Haryana was studied by exposing profiles, one each from different crop rotation and one from there nearby area. Most of the soils were light in texture and ranged from sand to clay. They were neutral to slight alkaline in nature. The organic carbon in Kaul soil varied from 0.38 to $0.48 \%$. In majority of the soils, the organic carbon content showed a decreasing trend with depth. Calcium carbonate was also present in these soils ranging from traces to as high as $1.25 \%$. The distribution of the different forms of the potassium i.e. water soluble, exchangeable, non-exchangeable and total potassium in these soils ranged from 8 to $58 \mathrm{~kg} \mathrm{ha}^{-1}, 127$ to $263 \mathrm{~kg} \mathrm{ha}^{-1}, 442$ to $828 \mathrm{~kg} \mathrm{ha}^{-1}$ and 1.18 to $1.92 \%$, respectively. The highest amount of the available and total potassium were found in Kaul soil, whereas, Bhiwani soil with sandy texture showed the lowest amount. No definite trend of different forms of potassium was observed with respect to depth in these soils. Correlation study showed that the different forms of potassium were positively and significantly correlated with organic carbon, silt and clay content of the soils. They were negatively correlated with sand content. The different forms of potassium were positively and significantly correlated among themselves.
\end{abstract}

Keywords: soil physico-chemical properties, distribution of potassium, water soluble-K, exchangeable-K, non-exchangeable-K, total-K, soil texture, crop rotations and correlation
Volume I Issue 2 - 2014

Jagmohan Saini,' KS Grewal'

'Agricultural Development Laboratory, Chambal Fertilizers \&

Chemicals Ltd, India

${ }^{2}$ Department of Soil Science, CCS Haryana Agricultural

University, India

Correspondence: Jagmohan Saini, Agricultural Development Laboratory, Chambal Fertilizers \& Chemicals Ltd., Kota, Rajasthan-324005, India, Tel +9I-8I07987890, Email jagmohan.saini@chambal.in

Received: May 20, 2014 | Published: June 25, 2014
Abbreviations: EC, electrical conductivity; FYM, farm yard manure

\section{Introduction}

Potassium is a major constituent of the earth crust contained more in igneous rocks than the sedimentary rocks. Potassium comprise on an average of $2.6 \%$ of the earth crust, making it the seventh most abundant element and fourth most abundant mineral nutrient in the lithosphere. ${ }^{1}$ Among the important $\mathrm{K}$ bearing minerals that are found in soil are feldspars and micas as primary and illites and transitional clay as secondary minerals. Soil K-minerals such as feldspars, illites and micas are present in abundant amounts in some soils. The information on vertical distribution of potassium in agricultural soils is important because it indicates the distribution of potassium with respect to depth of soils. It can indicate the depletion as well as accumulation pattern of potassium, if any, within the profile. A five-fold increase in food grain production during the last 35years combined with inadequate and unbalanced nutrient supply has led to a large degree of soil nutrient 'mining' of all the essential plant nutrient in the state of Haryana. In Haryana, farmers generally apply only nitrogen $(\mathrm{N})$, phosphorus $(\mathrm{P})$ and zinc $(\mathrm{Zn})$, as a consequence, deficiencies of potash $(\mathrm{K})$ and other nutrients are spreading in space and time. The intensity of nutrients $\left(\mathrm{N}+\mathrm{P}_{2} \mathrm{O}_{5}+\mathrm{K}_{20}\right)$ use through fertilizer in Haryana is $167 \mathrm{~kg} /$ ha consisting of $125.7 \mathrm{~kg} \mathrm{~N}, 38.7 \mathrm{~kg} \mathrm{P}_{2} \mathrm{O}_{5}$ and $2.6 \mathrm{~kg} \mathrm{~K}_{2 \mathrm{O}}$ with $\mathrm{N}: \mathrm{P}_{2} \mathrm{O}_{5}: \mathrm{K}_{2 \mathrm{O}}$ use ratio of $48.2: 14.8: 1$. The share of potash to total NPK consumption is only $1.55 \%$. The total potash removal by the crops in the state is reported to be 146,000 tonnes against total addition of merely 4,000 tonnes showing a negative potash balance of 142,000 tonnes and in consequence the potash reserve of the soils of the state has depleted. ${ }^{2}$ More than $98 \%$ of the total potassium reserve in soils and exists in inorganic combinations which can further be characterized as: water soluble $\mathrm{K}$, exchangeable $\mathrm{K}$, non-exchangeable $\mathrm{K}$ and lattice $\mathrm{K}$. Knowledge of different forms of potassium in soil together with their distribution is great relevance in assessing the long-term availability of potassium to crops and in formulating a sound basis of fertilizer recommendation. There is a paucity of information on the vertical distribution of potassium in different cropping sequences of Haryana. With this view, the present study was planned to achieve the following objective: -

"To study the vertical distribution of different forms of potassium in soils under different cropping sequences".

\section{Materials and methods}

In the present investigation of distribution of different forms of potassium in soils from different cropping sequences (pearl milletwheat; cotton-wheat; pearl millet-mustard; paddy-wheat; sorghumwheat) in Haryana was studied by exposing profiles, one each from different crop rotation and one from there nearby area. Total numbers of profiles exposed were ten. All the soil samples varied widely in their physico-chemical properties. The soil samples were collected, air dried ground and passed through $2 \mathrm{~mm}$ sieve and analyzed for various chemical properties. ${ }^{3}$ Clay content varied from 5\% in Bhiwani soil to $49 \%$ in Kaul soil. Kaul soil also exhibited a maximum CEC of $26.34 \mathrm{c} \mathrm{mol}\left(\mathrm{p}^{+}\right) \mathrm{kg}^{-1}$ followed by $11.59,10.87,8.69$ and $3.73 \mathrm{c}$ mol $\left(\mathrm{p}^{+}\right) \mathrm{kg}^{-1}$ for Hisar, Sirsa, Bawal and Bhiwani soil, respectively. 
All the soils were found to be slight alkaline in their reaction. None of the soil showed presence of $\mathrm{CaCO}_{3}$. Kaul soil had the maximum organic carbon content of $0.40 \%$ and Bhiwani soil had the least i.e. $0.17 \%$. Correlations between different forms of $\mathrm{K}$ and soil properties and among different forms of $\mathrm{K}$ were worked out by the procedure described by Panse and Sukhatme. ${ }^{4}$

\section{Results and discussion}

\section{Physico-chemical properties of soil}

The $\mathrm{pH}$ of the soil ranged from 7.4 to 8.4 (Table 1) indicating that the soils were slight alkaline in reaction. In general, it increased with depth. Low electrical conductivity (EC) in soil sample showed that the presences of salts in these soils was negligible and it varied from $0.12 \mathrm{dS} \mathrm{m}^{-1}$ in Bhiwani soil profile to $1.25 \mathrm{dS} \mathrm{m}^{-1}$ in lower depths Sirsa profile. A majority of the soils was non calcareous in nature whereas, in lower depth, $\mathrm{CaCO}_{3}$ contents was around $1.20 \%$. The organic carbon content of the profile exposed from different cropping sequences was low. It ranged from 0.16 to $0.48 \%$ but it did not follow any definite trend of increasing with soil depth. The low organic carbon content in soils samples under investigation may be due to its oxidation under prolonged higher summer temperature and high cropping intensity. No farm yard manure (FYM) has been applied to most of the soils for last many years which might be another reason for low organic carbon status of these soils. The cation exchange capacity of the soils ranged from 3.10 in Bhiwani soil profile to $31.05 \mathrm{c} \mathrm{mol}\left(\mathrm{p}^{+}\right) \mathrm{kg}^{-1}$ in Kaul soil profile and it also followed no definite pattern with soil depths. The particle size analysis (Table 1) showed that the texture of the different soil profile of the different cropping sequences of these areas was sandy to clay in nature. The clay, silt and sand content in these soil profiles varied from 3 to 58,3 to 30 and 16 to $93 \%$, respectively. There was no definite trend of the particle size distribution in these soils with respect to depths.

\section{Distribution of different forms of potassium and their relation with different soil properties}

The data on distribution of potassium in the profiles from different cropping sequences are presented in Table 2 . The relationship between different forms of potassium and physico-chemical properties as well as amongst the various forms of potassium is presented in Table $3 \&$ Table 4.

Table I Physico-chemical properties of different soils-A range

With cropping sequences

\begin{tabular}{lcccccc}
\hline Soils & $\mathrm{pH}(\mathrm{I}: 2)$ & $\mathrm{EC}\left(\mathrm{dS} \mathrm{m} \mathrm{m}^{-1}\right)(\mathrm{I}: 2)$ & $\mathrm{CEC}\left[\mathrm{cmole}\left(\mathrm{p}^{+}\right) \mathrm{kg}^{-1}\right]$ & $\mathrm{OC}(\%)$ & $\mathrm{CaCO}_{3}(\%)$ & Texture \\
Hisar & $8.0-8.4$ & $0.72^{-1} .1 \mathrm{I}$ & $10.14^{-1} 3.76$ & $0.22-0.33$ & - & $\mathrm{scl}$ \\
Koul & $7.4-8.0$ & $0.20-0.28$ & $24.20-28.32$ & $0.39-0.48$ & $0^{-1} .10$ & $\mathrm{c}$ \\
Sirsa & $8.0-8.4$ & $0.72^{-1} .11$ & $10.87^{-1} 3.76$ & $0.25-0.33$ & - & $\mathrm{scl}$ \\
Bawal & $8.2-8.4$ & $0.13-0.20$ & $5.59^{-1} 0.14$ & & \\
Bhiwani & $8.0-8.2$ & $0.13-0.16$ & $3.10-5.59$ & $0.20-0.29$ & - & $\mathrm{sl}$
\end{tabular}

Without cropping sequences

\begin{tabular}{|c|c|c|c|c|c|c|}
\hline Soils & $\mathrm{pH}(1: 2)$ & $E C\left(d S m^{-1}\right)(I: 2)$ & CEC $\left[\mathrm{c}\right.$ mole $\left.\left(\mathrm{p}^{+}\right) \mathrm{kg}^{-1}\right]$ & OC (\%) & $\mathrm{CaCO}_{3}(\%)$ & Texture \\
\hline Hisar & $8.0-8.4$ & $0.72^{-1} .11$ & $10.14^{-1} 3.76$ & $0.22-0.33$ & - & scl \\
\hline Koul & $7.8-8.0$ & $0.19-0.25$ & $27.58-31.05$ & $0.38-0.44$ & $0^{-1} .20$ & c \\
\hline Sirsa & $8.0-8.3$ & $1.04^{-1} .25$ & $10.87^{-1} 6.66$ & $0.27-0.34$ & $0^{-1} .10$ & scl \\
\hline Bawal & $7.9-8.4$ & $0.15-0.19$ & $6.21-9.42$ & $0.20-0.30$ & $0^{-1} .20$ & sl \\
\hline Bhiwani & $8.1-8.3$ & $0.12-0.17$ & $3.10-5.59$ & $0.16-0.21$ & $0^{-1} .20$ & $\mathrm{~s}$ \\
\hline
\end{tabular}

Note: scl, sandy clay loam; c, clay; sl, sandy loam; s, sand 
Table 2 Vertical distribution of different forms of $\mathrm{K}$ in different soil profiles of Haryana

\begin{tabular}{|c|c|c|c|c|c|c|c|c|}
\hline \multirow[t]{2}{*}{$\begin{array}{l}\text { Soil depth } \\
(\mathrm{cm})\end{array}$} & \multicolumn{4}{|c|}{$\begin{array}{l}\text { Profile I - Hisar with pearl millet-wheat cropping } \\
\text { sequence }\end{array}$} & \multicolumn{4}{|c|}{$\begin{array}{l}\text { Profile II - Hisar without pearl millet-wheat } \\
\text { cropping sequence }\end{array}$} \\
\hline & $\begin{array}{l}\text { WS-K } \\
\text { kg ha-1 }\end{array}$ & $\begin{array}{l}\text { EX-K } \\
\mathrm{kg} \mathrm{ha}^{-1}\end{array}$ & $\begin{array}{l}\text { NEX-K } \\
\mathrm{kg} \mathrm{ha}^{-1}\end{array}$ & $\begin{array}{l}\text { Total-K } \\
(\%)\end{array}$ & $\begin{array}{l}\text { WS-K } \\
\text { kg ha-1 }\end{array}$ & $\begin{array}{l}\text { EX-K } \\
\mathrm{kg} \mathrm{ha}^{-1}\end{array}$ & $\begin{array}{l}\text { NEX-K } \\
\mathrm{kg} \mathrm{ha}^{-1}\end{array}$ & $\begin{array}{l}\text { Total-K } \\
(\%)\end{array}$ \\
\hline $0^{-15}$ & 25 & 173 & 600 & 1.32 & 25 & 191 & 627 & 1.42 \\
\hline $15-30$ & 25 & 182 & 622 & 1.45 & 33 & 216 & 638 & 1.53 \\
\hline $30-60$ & 25 & 205 & 632 & 1.42 & 33 & 206 & 632 & 1.61 \\
\hline $60-90$ & 33 & 200 & 611 & I.55 & 33 & 210 & 648 & 1.58 \\
\hline $90^{-1} 20$ & 33 & 200 & 638 & 1.59 & 42 & 236 & 654 & 1.60 \\
\hline
\end{tabular}

\begin{tabular}{|c|c|c|c|c|c|c|c|c|}
\hline \multirow[t]{2}{*}{$\begin{array}{l}\text { Soil depth } \\
(\mathrm{cm})\end{array}$} & \multicolumn{4}{|c|}{$\begin{array}{l}\text { Profile III- Kaul with paddy-wheat cropping } \\
\text { sequence }\end{array}$} & \multicolumn{4}{|c|}{$\begin{array}{l}\text { Profile IV-Kaul without paddy-wheat cropping } \\
\text { sequence }\end{array}$} \\
\hline & $\begin{array}{l}\text { WS-K } \\
\mathrm{kg} \mathrm{ha}^{-1}\end{array}$ & $\begin{array}{l}\text { EX-K } \\
\mathrm{kg} \mathrm{ha}^{-1}\end{array}$ & $\begin{array}{l}\text { NEX-K } \\
\mathrm{kg} \mathrm{ha}^{-1}\end{array}$ & $\begin{array}{l}\text { Total-K } \\
(\%)\end{array}$ & $\begin{array}{l}\text { WS-K } \\
\mathrm{kg} \mathrm{ha-1}^{-1}\end{array}$ & $\begin{array}{l}\text { EX-K } \\
\mathrm{kg} \mathrm{ha}^{-1}\end{array}$ & $\begin{array}{l}\text { NEX-K } \\
\mathrm{kg} \mathrm{ha}^{-1}\end{array}$ & $\begin{array}{l}\text { Total-K } \\
(\%)\end{array}$ \\
\hline $0^{-15}$ & 33 & 237 & 767 & 1.78 & 42 & 248 & 787 & I.78 \\
\hline $15-30$ & 49 & 248 & 800 & 1.81 & 58 & 253 & 828 & 1.88 \\
\hline $30-60$ & 42 & 242 & 773 & 1.72 & 58 & 263 & 818 & 1.85 \\
\hline $60-90$ & 33 & 237 & 762 & 1.69 & 42 & 247 & 783 & 1.81 \\
\hline $90^{-1} 20$ & 42 & 252 & 818 & 1.84 & 49 & 257 & 828 & 1.92 \\
\hline
\end{tabular}

\begin{tabular}{|c|c|c|c|c|c|c|c|c|}
\hline \multirow[t]{2}{*}{$\begin{array}{l}\text { Soil depth } \\
(\mathrm{cm})\end{array}$} & \multicolumn{4}{|c|}{$\begin{array}{l}\text { Profile V - Sirsa with cotton-wheat cropping } \\
\text { sequence }\end{array}$} & \multicolumn{4}{|c|}{$\begin{array}{l}\text { Profile VI - Sirsa without cotton-wheat cropping } \\
\text { sequence }\end{array}$} \\
\hline & $\begin{array}{l}\text { WS-K } \\
\mathrm{kg} \mathrm{ha}^{-1}\end{array}$ & $\begin{array}{l}\text { EX-K } \\
\mathrm{kg} \mathrm{ha}^{-1}\end{array}$ & $\begin{array}{l}\text { NEX-K } \\
\mathrm{kg} \mathrm{ha}^{-1}\end{array}$ & $\begin{array}{l}\text { Total-K } \\
(\%)\end{array}$ & $\begin{array}{l}\text { WS-K } \\
\mathrm{kg} \mathrm{ha}^{-1}\end{array}$ & $\begin{array}{l}\text { EX-K } \\
\mathrm{kg} \mathrm{ha}^{-1}\end{array}$ & $\begin{array}{l}\text { NEX-K } \\
\mathrm{kg} \mathrm{ha-1}\end{array}$ & $\begin{array}{l}\text { Total-K } \\
(\%)\end{array}$ \\
\hline $0^{-1} 5$ & 25 & 191 & 611 & $\mathrm{I} .47$ & 25 & 218 & 627 & 1.50 \\
\hline $15-30$ & 17 & 182 & 600 & I.34 & 33 & 200 & 605 & 1.39 \\
\hline $30-60$ & 25 & 205 & 627 & 1.53 & 42 & 236 & 643 & 1.59 \\
\hline $60-90$ & 33 & 205 & 632 & I.57 & 42 & 218 & 640 & 1.58 \\
\hline $90^{-1} 20$ & 17 & 200 & 600 & 1.42 & 25 & 210 & 605 & 1.42 \\
\hline
\end{tabular}

Soil depth Profile VII - bawal with pearl millet-mustard (cm)

\begin{tabular}{|c|c|c|c|c|c|c|c|c|}
\hline & $\begin{array}{l}\text { WS-K } \\
\mathrm{kg} \mathrm{ha-1}\end{array}$ & $\begin{array}{l}\text { EX-K } \\
\text { kg ha-1 }\end{array}$ & $\begin{array}{l}\text { NEX-K } \\
\mathrm{kg} \mathrm{ha-1}\end{array}$ & $\begin{array}{l}\text { Total-K } \\
(\%)\end{array}$ & $\begin{array}{l}\text { WS-K } \\
\text { kg ha-1 }\end{array}$ & $\begin{array}{l}\text { EX-K } \\
\mathrm{kg} \mathrm{ha}^{-1}\end{array}$ & $\begin{array}{l}\text { NEX-K } \\
\mathrm{kg} \mathrm{ha}^{-1}\end{array}$ & $\begin{array}{l}\text { Total-K } \\
\text { (\%) }\end{array}$ \\
\hline $0^{-15}$ & 8 & 136 & 474 & 1.24 & 17 & 164 & 495 & 1.30 \\
\hline $15-30$ & 8 & 127 & 442 & 1.13 & 8 & 127 & 463 & 1.20 \\
\hline $30-60$ & 17 & 136 & 453 & 1.18 & 8 & 136 & 453 & 1.32 \\
\hline $60-90$ & 8 & 127 & 495 & 1.32 & 17 & 145 & 474 & 1.34 \\
\hline $90^{-1} 20$ & 17 & 145 & 463 & 1.26 & 17 & 164 & 484 & 1.26 \\
\hline
\end{tabular}

\begin{tabular}{|c|c|c|c|c|c|c|c|c|}
\hline \multirow[t]{2}{*}{$\begin{array}{l}\text { Soil depth } \\
(\mathrm{cm})\end{array}$} & \multicolumn{4}{|c|}{$\begin{array}{l}\text { Profile IX-Bhiwani with sorghum-wheat cropping } \\
\text { sequence }\end{array}$} & \multicolumn{4}{|c|}{$\begin{array}{l}\text { Profile } X \text {-Bhiwani without sorghum-wheat cropping } \\
\text { sequence }\end{array}$} \\
\hline & $\begin{array}{l}\text { WS-K } \\
\mathrm{kg} \mathrm{ha}^{-1}\end{array}$ & $\begin{array}{l}\mathrm{EX}-\mathrm{K} \\
\mathrm{kg} \mathrm{ha}^{-1}\end{array}$ & $\begin{array}{l}\text { NEX-K } \\
\mathrm{kg} \mathrm{ha}^{-1}\end{array}$ & $\begin{array}{l}\text { Total-K } \\
(\%)\end{array}$ & $\begin{array}{l}\text { WS-K } \\
\mathrm{kg} \mathrm{ha}^{-1}\end{array}$ & $\begin{array}{l}\text { EX-K } \\
\mathrm{kg} \mathrm{ha}^{-1}\end{array}$ & $\begin{array}{l}\text { NEX-K } \\
\mathrm{kg} \mathrm{ha}^{-1}\end{array}$ & $\begin{array}{l}\text { Total-K } \\
(\%)\end{array}$ \\
\hline $0^{-15}$ & 8 & 136 & 474 & 1.15 & 17 & 164 & 495 & 1.24 \\
\hline $15-30$ & 8 & 127 & 442 & 1.0 & 8 & 127 & 453 & 1.13 \\
\hline $30-60$ & 17 & 136 & 453 & 0.9 & 17 & 136 & 474 & 1.18 \\
\hline $60-90$ & 8 & 145 & 484 & 1.2 & 17 & 145 & 495 & 1.32 \\
\hline $90^{-1} 20$ & 8 & 127 & 463 & 1.2 & 17 & 136 & 463 & 1.26 \\
\hline
\end{tabular}

Note:WS-K, water soluble K; EX-K, exchangeable K; NEX-K, nonexchangeable K

Citation: Saini J, Grewal KS.Vertical distribution of different forms of potassium and their relationship with different soil properties in some Haryana soil under different crop rotation. Adv Plants Agric Res. 20I4; I (2):48-52. DOI: 10.15406/apar.2014.01.000I0 
Table 3 Correlation between different forms of $\mathrm{K}$ and soil properties

\begin{tabular}{|c|c|c|c|c|c|c|c|c|}
\hline Soil properties/forms of $\mathbf{K}$ & $\mathrm{pH}$ & EC & CEC & OC & $\mathrm{CaCO}_{3}$ & Sand & Silt & Clay \\
\hline WS-K & $0.579 * *$ & $0.279 *$ & $0.88 I^{* *}$ & $0.855^{* *}$ & 0.104 & $-0.848 * *$ & $0.525 * *$ & $0.887 * *$ \\
\hline Exch-K & $-0.548 * *$ & $0.324 *$ & $0.916 * *$ & $0.919 * *$ & 0.087 & $-0.916 * *$ & $0.648 * *$ & $0.917 * *$ \\
\hline Nonexch-K & $-0.570 * *$ & 0.163 & $0.979 * *$ & $0.954 * *$ & 0.049 & $-0.967 * *$ & $0.663^{* *}$ & $0.978 * *$ \\
\hline Total-K & $-0.490 * *$ & 0.107 & $0.936 * *$ & $0.916 * *$ & 0.047 & $-0.899 * *$ & $0.582 * *$ & $0.927 * *$ \\
\hline
\end{tabular}

Table 4 Correlation between different forms of $\mathrm{K}$

\begin{tabular}{lllll}
\hline Forms of K & WS-K & Exch-K & N Exch-K & Total-K \\
\hline WS-K & $1.000 * *$ & & & \\
Exch-K & $0.918^{* *}$ & $1.000^{* *}$ & & \\
Nonexch-K & $0.894^{* *}$ & $0.95 \mathrm{I} * *$ & $\mathrm{I} .000^{* *}$ & \\
Total-K & $0.863^{* *}$ & $0.91 \mathrm{I} * *$ & $0.940 * *$ & $1.000 * *$ \\
\hline
\end{tabular}

Note:WS-K, water soluble K; EX-K, exchangeable K; NEX-K, nonexchangeable K

*Significant at $5 \%$,**Significant at I $\%$ levels

Water soluble K: The water soluble potassium in the soil profiles ranged between $8 \mathrm{~kg} \mathrm{ha}^{-1}$ to $58 \mathrm{~kg} \mathrm{ha}^{-1}$. Maximum value of water soluble $\mathrm{K}$ was in paddy-wheat and minimum in sorghum-wheat cropping sequences. Mean values of water soluble $\mathrm{K}$ ranged from 11.6 to $49.8 \mathrm{~kg} \mathrm{ha}^{-1}$ and it contributed 1 to $3 \%$ towards total $\mathrm{K}$ in soil. This amount seemed to be quite inadequate to meet the major part of requirement of fast growing short duration crops for potassium. The values of water soluble potassium did not show any specific trend along the depth of soil. Higher values of water soluble potassium in subsurface horizons could be attributed to relatively higher amount of clay fractions and organic matter all along the profile depth and possibly more removal of water soluble potassium by crops under intensive cultivation from surface horizon then from subsurface horizons.

Correlation study of different forms with soil properties showed that water soluble potassium was significantly and positively correlated with EC $\left(\mathrm{r}=0.279^{*}\right)$, CEC $\left(\mathrm{r}=0.881^{* *}\right)$, organic carbon $\left(\mathrm{r}=0.855^{* *}\right)$, silt $\left(\mathrm{r}=0.525^{* *}\right)$ and clay $\left(\mathrm{r}=0.887^{* *}\right)$ content where as negatively correlated with $\mathrm{pH}(\mathrm{r}=-0.579 * *)$ and sand $\left(\mathrm{r}=-0.848^{* *}\right)$. It is interesting to note that the sand fraction was negatively and significantly correlated with all forms of potassium. This may be due to less content of potassium bearing minerals in sand fractions. Water soluble $\mathrm{K}$ data was correlated with different fractions of $\mathrm{K}$ and observed that it was highly and significantly correlated with exchangeable potassium $\left(\mathrm{r}=0.918^{* *}\right)$, nonexchangeable potassium $\left(\mathrm{r}=0.894^{* *}\right)$ and total potassium $\left(\mathrm{r}=0.863^{* *}\right)$. Similar results were also reported by Bhasker et al. ${ }^{5}$ Srinivassarao et al., ${ }^{6}$ and Setia et al. The better correlation of these forms of potassium with other forms indicates that the water soluble potassium was governed by the other forms of potassium like nonexchangeable and total potassium.

Exchangeable-K: The exchangeable $\mathrm{K}$ represents the fractions of potassium which is adsorbed on external and accessible internal surfaces. Exchangeable K content of these soils varied from $127 \mathrm{~kg}$ $\mathrm{ha}^{-1}$ in sorghum-wheat soil to $263 \mathrm{~kg} \mathrm{ha}^{-1}$ in paddy-wheat cropping sequence soil with a mean value of 134.2 to $253.6 \mathrm{~kg} \mathrm{ha}^{-1}$, respectively. The contribution of exchangeable $\mathrm{K}$ towards total $\mathrm{K}$ was 11 to $14 \%$. Considering $125 \mathrm{~kg} \mathrm{ha}^{-1}$ as general critical limits for crops, all the soils were high in exchangeable K throughout the depths. Samples from paddy-wheat cropping sequence contained higher amount of exchangeable $\mathrm{K}$ followed by pearl millet-wheat and cotton-wheat cropping sequences soils. In most of the profiles, no definite pattern of distribution of exchangeable $\mathrm{K}$ with depth was observed, which could be due to variation in clay content and organic matter of these soils. These results are in similar line as those of Yadav et al., ${ }^{8}$ for series of western Uttar Pradesh.

The values of correlation coefficient of exchangeable $\mathrm{K}$ with soil properties showed that exchangeable $\mathrm{K}$ was significantly and positively correlated with EC $\left(\mathrm{r}=0.324^{*}\right)$, CEC $\left(\mathrm{r}=0.916^{* *}\right)$, organic carbon $\left(\mathrm{r}=0.919^{* *}\right)$, silt $\left(\mathrm{r}=0.648^{* *}\right)$ and clay $\left(\mathrm{r}=0.917^{* *}\right)$ content where as negatively correlated with $\mathrm{pH}\left(\mathrm{r}=-0.548^{* *}\right)$ and sand $\left(\mathrm{r}=-0.916^{* *}\right)$. The sand fraction was significantly but negatively correlated with all forms of potassium this may be due to less content of potassium bearing minerals in sand fractions. Das et al. ${ }^{9}$ and Chand et al., ${ }^{10}$ also observed similar type observation in their studies. Exchangeable $\mathrm{K}$ was highly and significantly correlated with other forms of potassium i.e. water soluble potassium $\left(\mathrm{r}=0.918^{* *}\right)$, nonexchangeable potassium $\left(\mathrm{r}=0.894^{* *}\right)$ and total potassium $(\mathrm{r}=0.863 * *)$. The present findings are in similar line as that of Singh et al., ${ }^{11}$ and Gangopadhyay et al. ${ }^{12}$ The better correlation of this forms of potassium with other forms indicate that the different forms of potassium were in dynamic equilibrium with each other.

Nonexchangeable-K: Nonexchangeable-K is generally considered slowly released and available potassium to the plant under stress situations. The nonexchangeable-K content varied from 442 to $828 \mathrm{~kg}$ $\mathrm{ha}^{-1}$ with a mean value of 463.2 to $808.8 \mathrm{mg} \mathrm{kg}^{-1}$, respectively in these soils. Maximum value was in paddy-wheat cropping sequence soil and minimum was in sorghum-wheat cropping sequence soils. The percent contribution of nonexchangeable-K towards total $\mathrm{K}$ was 37 to $44 \%$ in these soils. In general, subsurface soils had higher amount of nonexchangeable- $\mathrm{K}$ compared to surface layers. The higher amount of nonexchangeable- $\mathrm{K}$ in paddy-wheat sequence may be due to presence of higher clay and organic carbon content compared to soils from other cropping sequences. However, no definite trend of distribution of nonexchangeable-K with depths of soil could be detected in any of the cropping sequences soil, which might be due to active pedoturbation processes operating in these pedons. These 
results are in agreement with Bhaskar et al. ${ }^{5}$ The higher values of nonexchangeable $\mathrm{K}$ in subsurface layers are related to silt and clay content of this layer. The lower amount in surface layers might be due to the release of fixed potassium to compensate the removal of water soluble and exchangeable potassium by planting and leaching losses. Similar results were reported by Das et al. ${ }^{9}$

Correlation study (Table 3) (Table 4) of nonexchangeable-K with soil properties showed that it was significantly and positively correlated with CEC $\left(\mathrm{r}=0.979^{* *}\right)$, organic carbon $\left(\mathrm{r}=0.954^{* *}\right)$, silt $\left(\mathrm{r}=0.663^{* *}\right)$ and clay $\left(\mathrm{r}=0.978^{* *}\right)$ content where as negatively correlated with $\mathrm{pH}\left(\mathrm{r}=-0.570^{* *}\right)$ and sand $\left(\mathrm{r}=-0.967^{* *}\right)$. The sand fraction was significantly but negatively correlated with all forms of potassium. This may be due to less content of potassium bearing minerals in sand fractions. Das et al., ${ }^{9}$ and Chand et al., ${ }^{10}$ also observed similar type of correlation in their soils. The nonexchangeable $\mathrm{K}$ was found to be positive and significantly correlated to water soluble potassium $(\mathrm{r}=0.894 * *)$, exchangeable potassium $\left(\mathrm{r}=0.951^{* *}\right)$ and total potassium $\left(\mathrm{r}=0.940^{* *}\right)$. This means that whenever fixed potassium was released, changed to available forms, there will be a simultaneous release of potassium from structural forms.

Total-K: The total K content in the different cropping sequences soils of Haryana ranged from 1.18 to $1.92 \%$ (Table 2). The higher total K content in Kaul soil (paddy-wheat) followed by Hisar (pearl milletwheat) and Sirsa (cotton-wheat) soils may be due to the presence of sufficient quantity of potash bearing primary minerals like feldspar and mica and it seemed to be directly related with clay and organic matter content of these soils also. Comparing the total $\mathrm{K}$ content among various subsurface soil horizons to surface horizons it was slightly lower in surface though it did not increase regularly with soil depths. This could be due to the effect of potassium depletion by the crops from the surface horizons. Singh et al., ${ }^{11}$ while conducting experiment on alluvial soils of Uttar Pradesh also observed higher values of total $\mathrm{K}$ in subsurface soils.

The total-K was significantly and positively correlated with CEC $\left(\mathrm{r}=0.936^{* *}\right)$, organic carbon $\left(\mathrm{r}=0.916^{* *}\right)$, silt $(\mathrm{r}=0.582 * *)$ and clay $\left(\mathrm{r}=0.927^{* *}\right)$ content where as negatively correlated with $\mathrm{pH}(\mathrm{r}=-$ $\left.0.490^{* *}\right)$ and sand $\left(\mathrm{r}=-0.899^{* *}\right)$. These relationship confirmed that the finer fractions of the soils are in primary sources of potassium in the soils of Haryana. The results also point out that the light textured soils would be depleted easily than heavy textured for native potassium. Therefore, continuous monitoring of soil potassium status is essential in these types of soils. Chand et al., ${ }^{10}$ and Dinagaran et al., ${ }^{13}$ also observed positive correlation between total $\mathrm{K}$ and CEC, organic carbon, silt and clay content. Total-K showed a highly positive and significant correlation with other forms i.e. water soluble potassium $\left(\mathrm{r}=0.863^{* *}\right)$, exchangeable potassium $\left(\mathrm{r}=0.911^{* *}\right)$ and nonexchangeable potassium $\left(\mathrm{r}=0.940^{* *}\right)$. The above relationship confirmed that availability of exchangeable, nonexchangeable and total potassium could significantly determine potentially available potassium in these soils. Similar results were obtained by Yadav et.al., ${ }^{8}$ in Vertisols of Madhya Pradesh.

\section{Conclusion}

The magnitude of different forms of $\mathrm{K}$ was lowest in Sorghumwheat cropping sequence and it was highest in paddy-wheat cropping sequence. The values of different forms of $\mathrm{K}$ did not show any definite trend with soil depths in any of the cropping sequence studied. The values of forms of $\mathrm{K}$ were compared with their non cropping sequence; the difference was higher in under pearl milletwheat cropping sequences. Different forms of $\mathrm{K}$ were significantly and positively correlated among themselves indicating the existence of equilibrium between them. The clay, silt, CEC and OC showed positive and significant correlation with all forms of $\mathrm{K}$ whereas sand fraction and $\mathrm{pH}$ showed negative correlation.

\section{Acknowledgements}

None.

\section{Conflict of interest}

The author declares no conflict of interest.

\section{References}

1. Schroeder D. Structure and weathering of potassium containing minerals. Proc. 11th Congr. Int. Berne: Potash Institute; 178. p. 43-63.

2. Tiwari KN, Yadav KS, Pal Bhisham. Breaking yield stagnation through balanced fertilization in Haryana. International Plant Nutrition Institute-India Programme; 2007. p. 1-24.

3. Jackson ML. Soil Chemical Analysis. New Delhi: Prentice Hall of India Pvt. Ltd; 1973. 98 p.

4. Panse VG, Sukhatme PV. Methods for Agricultural Workers. Indian Council Agri Res New Delhi; 1957.

5. Bhaskar BP, Vadivelu S, Baruah U, et al. Distribution of potassium forms and chars and marshy soils of Brahmaputra valley, Jorhat district, Assam. J Potassium Res. 2001;17(1-4): 39-47.

6. Srinivasarao C, Ganeshamurthy AN, Ali M, et al. Distribution of forms potassium in different soil type of pulse growing regions of India. $J$ Potassium Res. 2002;18:23-30.

7. Setia RK, Sharma KN. Vertical distribution of chemical pools of potassium and their relationship with potassium nutrition of wheat under longterm differential fertilization. J Indian Soc Soil Sci. 2004;52(4):469472.

8. Yadav NS, Verma RS, Trivedi SK, et al. Vertical distribution of forms of potassium in some soil series of vertisols Madhya Pradesh. J Indian Soc Soil Sci. 1999;47:431-436.

9. Das K, Sarkar D, Nayak DC. Forms of potassium and their distribution in some soils representing red and laterite ecosystem of West Bengal. $J$ Potassium Res. 2000;16(1-4):1-6.

10. Chand S, Swami BN. Different forms of potassium in some important soil associations of Bharatpur district of Rajasthan. $J$ Potassium Res. 2000;16(1-4):59-61.

11. Singh K, Malik RVS, Sing V. Distribution of forms of potassium in alluvial soils. J Potassium Res. 2001;17:116-118.

12. Gangopadhyay SK, Sarkar Deepak, Sahoo AK, et al. Forms and distribution of potassium in some soils of Ranchi plateau. J Indian Soc Soil Sci. 2005;53(3):413-416.

13. Dinagaran A, Singh Narendra, Grewal KS, et al. Distribution of potassium in some representative soil series of Haryan in relation to soil properties. Haryana Agric Univ J Res. 2006;36(2):113-118. 